Araștırma Makalesi - Gönderim Tarihi: 20 Șubat 2019 - Kabul Tarihi: 10 Haziran 2019

\title{
Etik Bir Değer Olarak Utanç Duygusu İnsan Olmanın Dayanılmaz Sessizliği
}

\author{
Sidıka Yilmaz ${ }^{1}$
}

\begin{abstract}
öz
İnsan psikolojik ve toplumsal bir varlık olarak hayatın içinde bir şeylerden hep utandı ve utanmaya da devam etmektedir. İnsanlık tarihi bu anlamda büyük bir utanç haritasına sahip; kimi utanma halleri unutulmuş ya da gerilerde kalmışken bir taraftan da yeni utanma konuları yaratılmaktadır. Bu haritanın nesiller ve kültürlerarası farklılık göstermesi, konunun etik/ahlaki bir alanda yer aldığının da göstergesidir; çünkü utanç konusu bir taraftan bir haslet, ama aynı zamanda da bir baskı unsuru olarak insani ilişkileri derinden etkileyen bir konumda yer almaktadır. Bu anlamda kadim zamanlardan günümüze utanç üzerine fikirler değişip dönüşse de sosyal alanın işleyişinde önemini korumaya devam etmektedir.
\end{abstract}

Modernite daha iyi bir hayat tahayyülü üzerine kuruluydu. Bir başka şekilde söylersek eğer, gelecek hep bir umut vadetmekteydi; insanın aklıyla daha iyi bir hayat kurabileceğine olan inanç ne yazık ki tahayyül edildiği gibi gerçekleşememiştir. Hayatın hızı, sorumluluk alanlarındaki değişimler, kent hayatının dayattığı yaşam tarzları ve pek çok nedenden ötürü bir diğeriyle kurduğumuz ilişki de değişip dönüşmüştür. Artık hiç kimse bir diğerine karşı sorumluluğunu yerine getirme isteğinde değildir. Eski duyarlılıklardan ve duygulardan yoksun bir hayatı deneyimlemekteyiz. Bauman, günümüz insanının hiçbir yükümlülük altına girmek istemediğini bu anlamda da insani pek çok sefalet ürettiğini söylemektedir (Bauman, 2005, s. 22). Bu oluşan hal/ sefalet durumu giderek daha çok bireyselleşen insanlar yaratırken, insan ile insan arasındaki ilişkide etik değerlerde bir eksen kaymasına da neden olmuştur. Bu eksen kaymasından en çok etkilenen, insani ilişkilerde merkezi bir konumda yer alan utanç duygusudur. Insanlık gelinen durumda utanmayla arasına mesafe koymuş, utanç bir haslet olmaktan neredeyse çıkartılmıştır. Kimsenin bir diğerinden utanması için bir gerekçesi bulunmamaktadır. İnsanlar arasındaki ilişkinin bir deneyimler alanı olduğundan hareketle utanç bu deneyim haritasındaki yerinden neredeyse kovulmuş gibi durmaktadır. Bu çalışma utanma konusunu iletişim ve etik kapsamında yeniden düşünme çabasıdır; Ege Üniversitesi İletişim Fakültesi İletişim Etiği dersi kapsamında

Alıntı: Yılmaz, S. (2019). Etik Bir Değer Olarak Utanç Duygusu İnsan Olmanın Dayanılmaz Sessizliği. Akdeniz Üniversitesi İletișim Fakültesi Dergisi, (31), sayfa no. 623-642 Doi:

1 Doç. Dr. , Ege Üniversitesi İletişim Fakültesi Gazetecilik Bölümü, sidika.yilmaz@ege.edu.tr Orcid No: 0000-0001-9516-5112 
2010 yılında gerçekleştirilen bir sınav üzerine temellendirilmiştir. Öğrencilerden, hayatlarının bir döneminde yaşadıkları bir utanma anını anlatmaları istenmiş, bu deneyimin etik analizini yapmalarını sağlayacak bir soru yöneltilmiştir. Sınav puanlaması etik analiz üzerinden gerçekleştirilmiştir. Puanlama dışı tutulan utanma ile ilgili anlatıların, olası bir akademik çalışmada yer alma intimaline karşı, öğrencilerden izin alınmıştır. Çalışmada tematik analiz (Herzog, Hitters ve Hande, s. 2019) yöntemi kullanılmıştır.

Anahtar kavramlar: Utanma, Çocukluk, Iletişim Ve Utanma, Utanma ve Etik Ilişsisi

\title{
Shame as an Ethical Value: The Unbearable Silence of Being Human
}

\begin{abstract}
As a psychological and social being, humans have always been ashamed of some things in their lives and they continue to feel so. In that sense, history of humanity has a large map of shame; while some conditions of being ashamed have been forgotten or have been left behind, new matters to be ashamed of are being created. Differentiation of this map according to generations and cultures is an indication that this subject is located in an ethical/moral domain; because the subject of shame has a deep impact on human relations as a matter of character on the one hand, and as an element of oppression on the other hand. In this respect, even though ideas about shame have changed and transformed since ancient times up to now, it continues to maintain its importance for the functioning of society.

Modernity was built on a vision of a better life. In other words, future was always a beacon of hope; unfortunately, the belief that human beings can build a better life through reason have not been realized as it was envisioned at first. Our relationship with other human beings have changed and transformed due to a plethora of reasons such as the speed of life, changes in areas of responsibility and life styles imposed on us through urban living. Nobody wants to fulfill their responsibility to others any longer. We are currently experiencing a life devoid of old sensitivities and feelings. Bauman talks about how today no one wants to take the burden of any responsibility, engendering a variety of human miseries (Bauman, 2005, s. 22). While this emerging condition/misery creates increasingly individualized human beings, it also causes an axial shift in ethical values related to relations between human beings. Located in a central position in relations between humans, the feeling of shame has been altered the most. At the current situation, humanity has put a distance to being ashamed, and shame is almost lost as part of human nature. Now, no one has a reason to be ashamed of another. Based on the idea that relations between human beings is the domain of experiences, shame seems to be erased out of its location from this map of experiences.
\end{abstract}


This study is an attempt to rethink shame in the context of communication and ethics; as a domain of emotion and experience between human beings, shame is among the subjects of communication ethics class. This study is based upon exam questions of Ege University Communication Faculty Communication Ethics class of 2010. The answers provided by students were considered important in the sense of bringing the past to today and through personal interviews, their consents were taken for a possible future study. The study has been conducted with the thematic analysis method (Herzog, Hitters and Hande, s. 2019).

\section{Giriș}

"Her yıl, insanı daha bir utanmaz kılmakta"

Canetti

K endimize utanma nedir ve hangi zaman diliminde hayatı belirlemeye ve insani duyguların içine yerleşmeye başlamıştır gibi bir soru sorduğumuzda, ulaştığımız ilk yer çocukluk olmaktadır. Theodore Zeldin'in İnsanlığın Mahrem Tarihi kitabı hayatlarımızdaki seçimler ve ben olma süreçlerindeki kişisel hikâyeler üzerine kuruludur; yazar sıradan insanların sıradan diyebileceğimiz kararlarına, karşılaşmalarına, beceriksizliklerine ve duygularına odaklanarak, hayat denen mucizenin aslında sağımızdaki solumuzdaki insanların hayatlarında gizli olduğunu keşfetmemizi sağlamaktadır. Kitap bu yanıyla aynı zamanda da insanların mahrem hayatlarının tanıklığını yaptırarak, utanma ve insan ilişkisi üzerine zengin bir deneyim alanının içinde dolaştırır; böylece, utanç duygusunun toplumsal yaşamın içinde bir diğeri ile kurulan ilişkinin lâbirentlerinde ortaya çıktığının farkına varma şansını elde ederiz.

Çıplaklık aslında ilk utanma duygumuz olabilir. Hans Peter Duerr'in Çıplaklık ve Utanç kitabı, insanın bedeniyle ve bir diğeriyle kurduğu ilişkinin haritasını ortaya koymaktadır. Bu haritada günümüz için şaşırtıcı olabilecek şey ise gündelik hayatın içinde birbirlerini görmek istemediklerinde yarattıkları hayali giysiler ve duvarlardır. Peru'nun kuzey doğusunda yaşayan Yagualar'da bütün aileler arada paravan olmayan büyük evlerde yaşarlar. Bu çok kalabalık yaşam biçiminde özel alan yaratmanın mümkün olmadığını düşünebiliriz. Oysa der Duerr "Bir erişkin ya da çocuk yalnız kalmak istediğinde, karakteristik bir tavırla evin palmiye yapraklarından örülmüş duvarına yaslanır. Bu duruşu aldığında, artık 'mevcut değildir' ve acil durumlarda bile kendisine hitap edilmez, hatta bakılmaz" (Duerr, 1999, s. 147-148). Çünkü bu topluluklarda fiziksel sınırların yanı sıra, ruhsal sınırların da bilinmesi gerekmektedir (1999, s. 150-151). Öte yandan Miletoslu genç kızlar arasında yaygın intihar vak'alarını önleyebilmek için intihar eden genç kızın cesedinin çıplak olarak pazar yerinde sergileneceği kararı alınır; kızlardan hiç biri, öldükten sonra onurunu bu şekilde yitirmeyi göze alamayacağından intihar olayları neredeyse biter (1999, s. 21). Tarihsel süreç bu anlamda çıplaklık, mahremiyet ve utanç arasındaki ilişkinin derin katmanlarını göstermektedir.

Arendt, yaşamın dur durak bilmeyen bir akış içinde sürekli olarak dalgalar halinde 
birbirine karıştığını (Arendt, 1994, s. 19) söylemektedir. Bu dur durak bilmeyen akış, kimsenin kimseyi pek de ilgi alanına katmadığı, katamadığı bir hayatı yaratmış durumdadır. Artık hiç kimse bir diğerinin yaşamına uzun süre tanık değil; çalışma koşulları, kentsel kurgu, arkadaşların birbirlerine karşı sorumluluğunu da (Sennett, 2002, s.19) azaltmıştır. "İnsanlar, bugün olduğu gibi, ötekinin toplam kişiliğinin parçalarıyla karşı karşıya kalmıyorlar, aksine, tüm kişiliğiyle muhatap oluyorlardı; bu yüzden de bireyin hatalı bir davranışı, günümüzün büyük şehirlisinin yaşamında olduğundan daha çok daha utanç verici sonuçlar doğurabiliyordu" (Duerr, 1999, s. 12). O nedenle Bir daha karşılaşma intimali bulunmayan insanların birbirlerine karşı sorumluluk duymadığı bir hayatın içinde bulunmaktayız. Kimsenin bir diğerine karşı sorumlu olmadığı, hayat boyu bir daha karşılaşma şansının bulunmadığı yer aslında tarafsız bir bölgedir (Yılmaz, 2012, s.140). Sokaklar, alışveriş merkezleri, yolculukta yan koltuğu buna örnek olarak verebiliriz. Buralardaki insanlara karşı herhangi bir sorumluluk duyulmaz, istenirse konuşulur, kimi zaman iç dökülür, tepki verilir ve hiçbir şey olmamış gibi de hayata devam edilmektedir. Böylesine karşılaşmalar utanç duygusunun bertaraf edildiği alanlardır.

Utanma kimi zaman yapılan bir davranış neticesinde yaşanır; bedensel bir dışa vurumdur -el kaldırmak gibi-, geri dönüşü yoktur; kimi zaman da zihnin kapılarının ardına kadar açılığı bir anda, ağızdan dökülen sözcükler bir utanmaya vesile olabilir. Bu nedenle utanmak bir diğeri karşısında aslında duygusal olarak da çıplak kalmaktır; bu hal en az fiziksel çıplaklık kadar yüksek bir utanç yaşatmaktadır. Duygular ve düşünceler gizlendikleri yerden bir şekilde dışarı taşarak, geri alınamaz hale gelmiştir. Hayat sürekli rasyonel bir alanda gerçekleşmediği için, aniden olan olaylar, duygular repertuarını harekete geçirerek, plansız, hiç beklenmedik tepkilere kapılarını sonuna kadar açabilmektedir.

Gazetecilik çoklu karşılaşmalar ve ilişkiler ağı içinde gerçekleştirildiğinden sosyal sorumluluğu yüksek bir meslektir. Utanç duygusu tıpkı samimiyet ve ilave edebileceğimiz diğer insani duygular gibi gazeteci için olmazsa olmaz bir yerde konumlanmaktadır. İletişim Fakültesi İletişim Etiği dersinde utanç konusu etik bir gereklilik olarak hatırlatılmakta ve ders kapsamı içinde meslek pratiğini etkileyen taraflarıyla incelenmektedir. Çalışma 2010 yılında geçekleştirilen etik sınavında puanlama dışı tutulan anlatılar üzerinedir.

Öğrencilerden o güne kadar hafızalarında yer etmiş bir utanma anını aktarmaları istenmiş, bu utanma deneyimi ile ilgili etik analiz yapacakları bir soru sorulmuştur. Yazacakları öznel deneyimin puanlamaya dâhil edilmeyeceği önceden kendilerine duyurulmuştur.

Mevcut analiz materyali, katılımcıların ad ve soyadlarının baş harfleri, cinsiyet ve katılımcı numarasına göre kodlanmıştır. Örneğin 88. kağıt, Sabiha Yeşil "SY/K 88" şeklinde analize dâhil edilmiştir. 


\title{
Kuramsal Çerçeve
}

\author{
"Utanç silinmez. \\ Gitsin demekle gitmez" \\ J. M. Coetzee
}

Zeldin'e göre iletişim "bazen daha yüksek, bazen daha düşük hata payıyla çalıştığımız ve doğruluğundan asla bütünüyle emin olamayacağımız bir tercüme işidir. Tam anlamıyla başka birinin zihnine girmemizi sağlayacak bir anahtar yoktur" (1998, s. 249). Dolayısıyla utanma bu iletişim alanının içinde, çoğunlukla da değerler haritasının dayattığı yerden işler; özel alan ile kamusal alanın bize biçtiği benlikler arasında dolanırız. Bergson biteviye bir değişim içinde olduğumuzu söylemektedir; bu öylesine bir değişimdir ki kendimiz bile bunun farkına varamayız. O nedenle de şekilsiz, kayıtsız ve değişmez bir ben tahayyül etmiş sonra da bunun üzerine müstakil, sabit varlıklar varmış gibi davranırız. Oysaki değişmeyen bir ben yoktur (2017, s.7579). Bu değişimi fark edebilmenin koşulu, hayatımızda değiştirici dönüştürücü bir vak'a ile karşılaşmaktan geçmektedir. Bir gün bir şey olur, işte o zaman kendimizdeki değişimi kavrama şansını buluruz. Utanma böyle bir kırılma anını yaratmaya muktedir olabilir; büyük ya da küçük bir durum olması fark etmez, insanı sarsan kendisi üzerine düşünmeye iten, sorgulatan bir hal olarak utanma varoluşun bir nevi sigortasıdır.

İletişim bir bakıma anlamlandırma çabasıdır; utanma iletişimin bu karmaşık haritasının içinde gerçekleşir ve bir diğerini anlama konusunda kimi önemli ipuçları sağlayabilir. Utananın duygusal zayıflığı karşı tarafa yargılama gücü verebilir -utanma kimi zaman bir şeylerin ters gitmesidir- ama aynı zamanda da insani bir haslet olarak bir diğeriyle kurulan ilişkiyi olumlu anlamda belirleyip dönüştürebilir; her hâlükârda etik bir alana işaret edilmektedir. Bu nedenle de "Hangi yaşta veya konumda olursak olalım, utanç bizim için en katlanılması zor duygulardan biridir" (Hatchkiss. 2014, s.24). Hayat boyu kişiyi takip ederek, yaşam kalitesini etkileyecek şiddeti de barındırabilmektedir. Bu çalışma kapsamında yer alan utanma konularının yoğunlukla çocukluk dönemine ait olması, dolayısıyla anlatıcıların hayatları boyu etkisinde kaldıkları bir meseleye dönüşmesi bu saptamayı doğrular niteliktedir.

Utanma ahlaki bir değer olarak bir yanıyla patalojik, birbirimizle kurduğumuz ilişkide iletişimi bozan bir hal; ama aynı zamanda insan ile insan arasındaki ilişkide bir diğerine gösterilen insani dikkati içerir. İnsanın kimi davranışları bazen kendiliğinden, şaşırtıcı bir hızla gelişebilir; iletişimi zorlaştıracak, hatta imkânsız hale getirecek bir utanma böylelikle gerçekleşmiştir. Bu hassas dengede insanlar arasındaki ilişkiyi nezaketli bir alana çekebilmenin yöntemi bir diğerini düşünmek konusundaki dikkatlerle ilişkilidir. İnsan, utandığı veya utandırdığı an aslında sahip olduğu ahlaki değerlerin yapısını ortaya koyar. Bu anlamda utanma ahlaki sorumluluk duygusuna ait bir fiziksel ve zihinsel reflekstir. Bir şey hayatımızda çok hızla gerçekleşebilir ve o hız karşısında kendiliğinden yine hızla bir pozisyon alabiliriz; kimi zaman bu karar kişiyi utandıracak bir yere taşıyabilir. Ama bu durum, düşünülerek karar verilerek gerçekleşmemiştir. Bu anlamda çoğu zaman utanç, "söylemsel hazırlığı olmayan, düşünümsellik öncesi bir durumdur, o nedenle de bilinçli bir şekilde utanmak -çoğu zaman- olanaksızdır. 
Ama bir taraftan da toplum içinde kurulan bir ruh yetisidir. Bu yüzden utanç benliğin ya da bilincin ilkel bir bileşenidir" (Taburoğlu, 2017, s.83). Bu nedenle, hayatın içinde nedenleri üzerinde durmadan, hatta onların ne olduklarını bile tam anlamadan hayata devam ettiğimiz pek çok utanma hali bulunmaktadır. Bunlar bir yanıyla kabullenilmiş, zaten öyle olması gereken hallerdir; diğer yanıyla da ahlaki bir zeminin belki de yine kendiliğinden işlediği alanlardır.

Erving Goffman'ın da belirttiği gibi hayatın içinde anlık yaşadığımız hadiseler o anda olup biterler ama aynı zamanda da kocaman bir etkiye sahiptirler. Oysa kısa hikâyelerde olduğu gibi bir şey olmasını bekleriz, o şey olmuştur ama giriş gelişme sonuç olmadığı için sersemleriz. Goffman'ın anlattığı hadiseler an'lardır ve tüm hikâye orada olup biter. Freud'dan yola çıkarak dil sürçmeleri, potlar, gaflar veya sözcüklerin yanlış kullanımı olarak gündelik hayatın psikopatolojisi olan şeyler insanlar arasındaki önemli hadiselerdir (Goffman, 2018, s. 49-50) ve bir şekilde birilerinin utandığı anları yaratırlar. Statü olarak birbirinden farklı ama bir şekilde arkadaşlık kuran insanların derin bir sohbetin ardından koridorda yürüyüp bir kapıdan geçmek durumunda kaldıklarındaki hâl, yani o an, yine sorunlu bir andır ve hayatın içinde bir hadiseyle karşı karşıya kalmak demektir (2018, s.50). O güzelim sohbet kapıdan kimin öncelikli geçeceği gerçeğine çarpmıştır. Hayat bizleri bu tür hadiselerle karşı karşıya bıraksa da aslında tüm hayatı bu hadiseleri önemsemiyormuş gibi yaşarız. Ufak, küçük, önemsiz gibi duran bu hallerin derin etkileri üzerine pek de konuşmayız. "Karşılaşmalar esnasında birey, hadiselere, sanki meydana gelmemiş gibi muamele ederek bu hadiselerle başa çıkmaya mecburdur" (2018, s.56). Ancak insanın davranış setleri her zaman plan ve program içinden çıkmayacağı için tüm karşılaşmaların aslında bir oyun alanı içinde, o ana içkin, kendiliğinden diyebileceğimiz davranış setleri içerdiğini söyleyebiliriz. Hayat plan ve program yaparak, belli stratejiler üzerinden yaşanmayacak kadar karmaşık hadiselerin içinde tutar insanı. Dolayısıyla sonsuz bir çeşitlilik ve akış halinde bir hayatın içinde, yılların birikimi olan deneyimler bile çoğu kez insanı zorlu alanlardan kurtarmaya elvermez.

İnsan kimi zaman da kendisinden utanır. İnsanı kendisinden dahi utandıracak hallerin neler olduğuna ilişkin çok katmanlı karmaşık cevaplar aransa da, aslında belki de bir diğerinin varlığı utanmak için başlı başına bir neden olabilir. Çünkü tüm karşılaşmalar bir sınav alanı olarak işler ve tüm karşılaşmalar aynı zamanda da bir oyun alanıdır. "Sosyallik, kişinin sanki herkes eşit '-miş gibi yaptığı' ve aynı zamanda onların her biri tarafından onurlandırılıyormuş gibi davrandığı oyundur" (Gofmann, 2018, s.22). Modern hayat bu eşitsizliğin üzerine kuruludur ve hesaplanabilir kuralları talep eder. Oysa hayatın akışı rasyonel hesaplamaların dışında pek çok duyguyu dolayısıyla irrasyonaliteyi de barındırmaktadır. Duygular haritasından hangisinin ne tür bir durum karşısında harekete geçeceği çoğu zaman bir bilinmezlik taşımaktadır. Gelinen durumda geçmişin deneyimlerinin değerini yitirdiği, hızın ve çoklu medyatik ortamların insan ile insan arasındaki iletişimi farklı bir alana taşıdığı -insansız iletişim- bir hayatı yaşamaktayız. Utancın bu yeni ve tanımlamakta zorluk yaşadığımız sosyal hayatın neresinde durduğu ve hâlâ bir değere sahip olup olmadığı sorusu/konusu ise tüm ciddiyetiyle önümüzde durmaktadır. 


\section{Yöntem ve Analiz}

Çalışma, 2010 yılında İletişim Etiği dersi sınav sorusunun değerlendirme dışı bırakılan "deneyim anlatısı" kısmının analizi üzerine temellendirilmiştir. Toplam 95 kâğıt analize tabi tutulmuştur.

Çalışmada tematik analiz (Herzog, Hitters ve Hande, 2019) yöntemi uygulanmıştır. Tematik analiz, tekrar eden tecrübelerden anlamlı bir bütün elde etmeye yöneliktir ve temel yapılara odaklıdır. Mevcut temaların tekrarları, bu tekrarların sadece tek bir söze sığmayacak bir anlatıya dönüşmesi, tematik analizi seçmede önemli bir kıstas olmuştur. Öte yandan tematik analizin insan tecrübeleri ve anlayışlarına odaklanması; nitel veriyi analiz etmekte geniş bir yelpazeden/çerçeveden bakabilme önerisi; tekrarlayan yapıların varığını önemli bir veri olarak kabullenmesi açısından önemsenmiştir. Bu çalışma, belirlenen üç temel tema üzerinden gerçekleştirilmiştir. Bunlardan ilki, toplumsal ve kültürel kodların toplumsal yapılar içinde inşa edildiği gerçeğidir. İkinci tema hatırlama ve hafıza üzerine olmuştur; insanın geçmişle kurduğu bağ -hatırlamalar alanı- ile utanma arasındaki güçlü bir bağ bulunmaktadır. Üçüncü olarak da hatırlanan geçmiş hikâyeleştirilerek anlatıya dönüştürülmektedir. Hatırlanan küçük bir an dahi olsa, anlatıcı bunu o günlerin koşulları, kişisel duyguları, aile hikayeleri ile birleştirerek anlatmaktadır.

Metinler bir yanıyla etik okumayı talep ederken, aynı zamanda da toplumsal bilgi üretme alanlarına bakmayı gerekli kılmıştır. İnsan yaşamının deneyimler toplamı olduğundan yola çıkarak deneyim insan ilişkisi çalışmanın bir diğer dikkat noktasını oluşturmuştur. Dolayısı ile bu metinlerin okunmasında Agnes Heller'in (2006) Bir Ahlak Kuramı; Martin Jay'ın (2012) Deneyim Şarkıları Kitabı; Pierre Bourdieu'nun habitus (2012), Habermas'ın (2001) yaşam evreni kavramları; Maurice Halbwach (1992), Paul Connertan (1999) ile Bergson'un $(2017$; 1947) bellek, hatıra, hatırlama ve unutma üzerine söyledikleri temel referans kaynaklarını oluşturmaktadır.

\section{Bulgular}

Aşağıda bulgular 3 tema altında sunulmaktadır.

\subsection{Toplum/Kültürel Kodlar Bize Ne Yapar?}

“Utanç, Dünya'yı bir tek utanç kurtarabilir” Ingmar Bergman

Gündelik hayat topluca öğrenilen bilgilerin tekrarıyla gerçekleşmektedir. Beğenelim beğenmeyelim, tartışılmadan kabul edilmiş, bir süre sonra normlara dönüşmüş olan davranış setlerimiz bulunmaktadır. Böylece gündelik /toplumsal hayat bunların işlediği, görünür kılındığı bir hikâye alanı olarak işlemektedir. Yaşanılanların hikâyeleşmesi 
ya da deneyimlerin bir parçası haline dönüşmesi, toplumsal yapının içinde meseleye nasıl bakıldığıyla da alâkalıdır. Bazılarının rahatlıkla yaptıkları sıradan şeyler, kimileri için dünyanın en zor işine dönüşebilmektedir. Gülayşe Koçak Gözlerindeki şu hüznü gidermek için ne yapmalı? Romanında kahraman bir türlü bahşiş vermeyi beceremez; o an gelmeden strese girmeye başlar. Bir bahşişin nasıl verileceği onun için büyük bir sorundur. Karşı tarafın cebine ya da eline para sıkıştırmayı genel temayüllerin aksine karşı tarafı aşağılayıcı bir eylem olarak görür. Bu temas çok utanç vericidir (Koçak, 1997, s.70-71). Gündelik hayat bu tür yapmaktan çekindiğimiz pek çok davranış setiyle bizi sınar.

SS/E 84. "Ortaokul yıllarımda folklor ekibinde oynuyordum. Daha ilk seçmelerde hocam beni yetenekli bulup seçmişti. (...) O gün bizim için çok fazla güzel ve önemliydi. Çünkü oyunumuzu 23 Nisan günü tüm köy halkının önünde sergileyecektik. Okul çıkışı eve gittim hemen aileme haber verdim. Ertesi gün tekrar okulda hoca bizi çalışmak için spor salonuna çağırdı. Gittiğimizde çok şaşırmıştık. Çünkü salonda ilk günkü gibi sadece bizim gibi erkekler yoktu. Alt sınıfın kızları da vardı. Önce ne olduğunu anlamadık fakat daha sonra onlarında folklor ekibi için seçilmiş olduğunu anlamıştık. Buraya kadar olanlar benim için normaldi. Fakat utanmama neden olacak olay ondan sonra başladı. Hoca kız arkadaşlarımla el ele tutuşmamızı istedi. Başta benim için imkânsızdı bu. Ama daha sonra hocamızın zorlaması ile tutuştuk. Gerçekten çok utanmıştık."

Gündelik hayatın içinde bazı davranışları yapmak yukarıdaki örnekte olduğu gibi son derece zor olabilir. Üzerinde durulması gereken bu davranışların neden zor olduğu ve neden utanç meselesi haline geldiğidir. Öğrencilerin unutamadıkları utanma hikâyelerinin pek çoğu yetişme dönemlerine aittir. Arkadaşının elini tutma konusunun hayatı boyunca unutamayacağı bir meseleye dönüşmesindeki temel sorun, gündelik hayatın içinde bu tür yakınlıklar hakkında üretilen bilgilerdir. Konu hakkında toplumsal olarak inşa edilen "ayıp" bilgisi olaylar ve durumlar hakkında nasıl davranmaları gerektiği bilgisini de vermektedir. Sokakta ayıp olan okul alanında ayıp olmayınca yaşanan duygu utanç olmuştur. Okul, aile, yakın akraba, komşuluk ilişkilerinde beklenen davranışları sergilemediği için tepki gören; öğretmeninin istediği spor ayakkabıyı alamadığı için tüm arkadaşlarının önünde sorumluluğunu yerine getirmemiş duygusu yaşatılan çocuk, hayat boyu unutamayacağı bir utanç duygusu içine girmektedir. Hayat karşısında yeterli bilgiye sahip olmayan çocukların, gündelik hayatla kurdukları bağ utanma ve utandırılma deneyimleri üzerine kurulmuş olmaktadır.

Freud toplulukların birlik oluşturmak için duygusal bir bağa intiyaç duyduklarına vurgu yapmaktadır. Ona göre, iki kişi arasında anne baba çocuk ve dostluk arkadaşlık gibi uzun ömürlü ilişkilerde ister istemez bir mahremiyet algısı ortaya çıkar. Her bir mahrem ilişki de dipte mutlaka bir yadsıyıcı ve düşmanca bir duygulardan bir tortu taşımaktadır (1975, s. 44). Bu tortular geriye itimler dolayısıyla algılara kapalı kalır ama çeşitli nedenlerde bir araya gelme hallerinde düşmanlıklar, duygusal patlaklar verir. Tuhaf olan da bu karşı çıkışların bizleri şaşırtmayışıdır (1975, s.44-45). Öğrencinin ilkokul yıllarında kız arkadaşının elini tutma konusunda büyük utanç yaşaması Freud'un belirttiği dipteki yadsıyıcı duyulardan bir tortunun varlığını teyit etmektedir. O küçük hareketi yapılamaz hale getiren karşılaşmalar, söylemler, utandırmalar bir yerlerde öylesine gizlenmiştir ki, o duruma ilişkin bir karşılaşma, örneğimizde olduğu gibi, büyük bir utanma hikâyesine dönüşmüştür. 
Toplumsal örüntü aynı zamanda büyük bir oyun alanı olarak iş görmektedir (Huizinga, 1995). Bourdieu ya göre oyun bir diğeri karşısında kendi gerçekliğimizi kabul etme alanıdır. Oyundaki başarının nedenlerini anlamaya odaklanan Bourdieu, herkesin bilgisi dâhilinde olan şeyleri bazılarının daha iyi yapabiliyor olmasını anlaşılır kılmaya çalışır. Bulduğu şey, mükemmel ve vasat atlet arasındaki farkın sadece fiziksel yeteneğe bağlı olmayıp, aynı zamanda da güven, konsantrasyon ve uygun fırsatlar yaratma becerisiyle de ilgili olduğudur. Bu zor karışımı yapabilenler oyunu kazananlar ya da kazandıranlardır. Yetenek denilen şey ona göre oyuncunun habitusunun bir parçasıdır. Biriktirdiği pek çok şey kendisinin bile farkında olmadan oyun sırasında devreye girer. Bu fark, Bourdieu'ya göre, hayatın eşitsizliklerini de öğrendiğimiz yerdir ve mantıklı olarak neyi bekleyebileceğimizi öğrenerek habitusumuza katarız (akt. Calhoun, s. 80-81). "Ancak oyunları kendimiz icat etmeyiz, onlar tarihin, toplumsal mücadelelerin ve daha önce doğaçlamaların ve aşk yapmanın aile kurmanın çocuk yetiştirmenin doğru yolunu söyleme kapasitesine sahip güçlü aktörlerin dayatmalarının ürünüdürler" (Bourdieu, 2012, s.29).

Goffman'a göre de hayatın içinde tek başına kimlik temin etmek yeterli değildir; faaliyetlerin toplumsal olarak da tesis edilmesi ve anlamlandırıması gerekir (2018, s.71). Bourdieu da toplumsal hayatın düzenli ve öngörülebilir oluşunun dış baskılar olmadan gerçekleşme kapasitesinin olabilirliğini sorgulamaktadır. Bu anlamda toplumsal failler habitusları benimser onaylar ve yeniden üretirler. Aynı zamanda da aktörün içinde bulunduğu toplumsal bağlamın etkisini devreye sokarak, genel geçer bilginin içinden genel davranış setlerini yeniden üretirler (akt: Tatlıcan, Çeğin, 2014, s. 315) "Habitus, kelimenin tam anlamıyla, ne tam olarak bireyseldir, ne de davranışları tek başına belirler; buna karşın, eylemcilerin içinde işleyen yapılandırıcı mekanizmadır. Eyleyicilerin çok çeşitli durumlarda başa çıkmasını sağlayan bir strateji üretme ilkesidir" (Bourdieu, 2012, s. 27). Toplumsal failler olarak hep birlikte inşa ettiğimiz bir gerçeğin, bir utanma hikâyesine nasıl gizlendiğini aşağıdaki örnekte görebiliriz. Öğrenci aynı zamanda bu sorunla nasıl baş etmeye çalıştığını aktarmaktadır:

$\mathrm{MH} / \mathrm{K}$ 52. "Küçükken, sokakta oynamak için akşam geç saatlere kadar dışarıda kalırdık ve ailem erkenden eve girmem için "Çingeneler kaçırır seni!" diyerek beni korkutmaya çalışıyorlardı ve nitekim de başarıı oldular. Aktüel dil içinde ailem çingeneleri, çalışacak güçte oldukları halde çalışmayan, çocuklarını dilendiren hırsızlar olarak görüyorlardı. Medya da bunların körükleyicisi konumdaydı. Ailem, ben ve diğerleri hiçbir zaman onlarla iletişime geçmedik. Onları anlamaya, tanımaya çalışmadık. Hırsızlık yapanın ahlaksız olduğu kanaatine varıp bunların nedenini düşünmedik, sorgulamadık. Tehdit olarak gördük. (...)Genel ahlaki değerlere uygun davranmalarını bekleyen toplum, ne onları anlamaya ne de tanımaya çalıştılar. (...) Romanları anlatan bir belgesel izlemiştim. Orada Türkiye'de yaşayan romanların nereden geldiğini, geleneklerini, yaşam tarzlarını anlatıyordu. Bu belgesel sayesinde farkındalığım arttı ve onları anlamaya, tanımaya başladım. (...)Onları görmezden gelerek bir insana yapılacak en kötü davranışta bulunmuştum. Gerçekten utanıyorum fakat artık farkında olarak yaşıyorum."

Hayatı kendi kişisel deneyim, düşünce ve kararlarımızla yaşıyor olduğumuz bilgisi her zaman doğru değildir; aslında, içinde yaşadığımız toplum, kültür -habitus- neleri önemseyip, benimsememiz gerektiğini bir şekilde öğretir. Kimi bilgilerin gerçek 
olmadığını hatırlatacak bir şey/olay/durum yaşayana kadar bu öğrenilen bilgileri doğru kabul eder, o bilgileri üretmeye ve korumaya devam ederiz. Bu koruma, ancak, hayatın bir kesitinde karşılaşılacak kimi durumlarla sorgulanır hale gelebilmektedir. Utanç deneyimi, bu değişimi yaratabilecek önemli bir duygu olarak çıkıyor karşımıza. Yukarıdaki örnekte, öğrencinin Çingeneler hakkındaki olumsuz yargıları izlediği bir belgesel sayesinde değişmiştir. Baumann bu anlamda Bireyselleşmiş Toplum kitabında bütün toplumları anlam fabrikaları olarak görerek şöyle demektedir:

"Onaylanan, paylaşılan, yüceltilen paylaşma edimiyle ve paylaşılana saygı duymak için açık ya da zımni bir anlaşmayla yüceltilen toplum dediğimiz şey tam da bunu yapan devasa bir acayip aygıt; toplum onaylama ve paylaşmanın öteki adıdır, ama aynı zamanda onaylanmış olanı ve paylaşılanı yüceltilmiş hale getiren güçtür. (...) Toplumun içinde yaşamak-onaylamak, paylaşmak ve paylaşıı̆ımız şeye saygı göstermek- mutlu yaşamanın (sonsuza dek sürmese de) tek reçetesidir" (2005, s.10).

Connertan da, toplum içinde kimi kural ve yönergeleri sorgulamadan, onlara uygun bir biçimde davrandığımızı söylemektedir. Davranış alışkanlıkları ona göre dil öğrenmede olduğu gibi kurallar ve formüller olmadan öğrenilir. O yüzden insan davranışlarının önemli bir bölümü alışkanlık üzerine kuruludur. Kuralların ve alışkanlıkların ne zaman devreye girdiğini önemlidir (Connerton, 1991, s.53-57) Connerton birçok davranış setini anlayabilmek için alışkanlık dediğimiz şeylere dikkat etmemiz gerektiğini söylemektedir. Gündelik hayatın içinde alışkanlık insanlar sorun etmedikleri bir alandır; diledikleri zaman ondan kurtulabileceklerini düşünürler. Oysa durum Connerton için hiç de öyle değildir. Onların gücünü iyi/kötü olarak değerlendirilen alışkanlıklara bakarak daha iyi anlayabileceğimizi söylemektedir. Sigara içmek de, günde bir elma yemek de bir alışkanlık olarak kodlanmaktadır. Bu alışkanlıklardan kurtulmaya çalışıldığında, ne kadar zor bir durumla karşı karşıya kalındığını hatırlamamızı istemektedir. Bu anlamda bir şeye alışmış olmak ona göre sıradan bir şey değildir (1991, s.145). Alışkanlıkların böylesine güçlü köklere sahip olmaları, onlardan kurtulmayı da zorlu hale getirmektedir. Toplumsal arenada da pek çok eylemimiz bu alışkanlıklar üzerinden devam etmektedir. Davranış setlerimizdeki otomatik halleri, utanma hikâyelerinde olup biletenleri, alışkanlık belleği üzerinden anlayabilmek de mümkündür. Alışkanlık belleği bu yüzden gündelik hayatın iletişim alanını belirler (1991, s.60). Bir başkasının alışkanlığına çarpmak utanma ile ilgili unutulmaz bir hikâye yaratabilir; utanılan şeyler, gündelik hayatın sıradan halleri gibi dursa da, aslında, kimi zaman da -kişisel tarihler nezdinde bakıldığında- kimlik/ benlik dediğimiz şeyi çok derinden etkilediklerini görmekteyiz.

AA/K 9. "Çocuklukta yeni arkadaş çevresi edinmeye başlamıştım. Maddi olarak durumları bizden, benim ailemden daha iyi olan bir arkadaşımın evine gittim bana tatı ikram ettiler, tatlıyı yedikten sonra susadım ve arkadaşımın içtiği bardaktan su içtim. Düşünerek yaptığım bir hareket değildi fakat annesi ve annesinin arkadaşları aynı bardaktan su içmemi ayıpladılar. Şöyle yorumları oldu "hayır aynı bardaktan su içemezsin, sağlıklı değil annen sana evde böyle mi öğretti dediler. Çok utandım."

Alışkanlıkların güçlü köklere sahip olduğu gerçeği yukarıdaki su içme pratiğinde çok net bir biçimde gözlenmektedir. Üzerinden uzun yıllar geçmiş olmasına rağmen, ayıplanmış olmak, çocuğu bir utanma sarmalının içine çekmiş ve hayat boyu unutmayacağı bir 
meseleye dönüştürmüştür. Yıllar öncesine ait, son derece basit, sıradan gibi duran bu örnek, utanmanın gücünü, küçük hallerin etkisini, deneyimlenen anların önemini en yalın haliyle aktarmaktadır.

BÜ/K 13. "X dersinde sınav olacaktık. Hoca soruları kendi söyleyecek biz kâğıtlarımıza yazacaktık. Yani şu an elimde bulunan kâğıttaki gibi hazır sorular durmuyordu önümde. Hoca soruları sıralamaya başlamıştı. Bu arada kulağımda işitme kaybı var, çevremle çok da sağlıkı iletişim kuramıyorum. Soruları tam anlamıyor, yazamıyordum. (...) arka sıramda oturan arkadaşımdan bakmak zorunda kaldım. (...) Sınavın ilerleyen zamanlarında hoca sınıfa bir şeyler sormuştu. Yine duymuyordum yanımdaki arkadaşa ne dedi hoca diye sordum. Hoca tabi ki konuştuğumu sandı ve şöyle dedi 'hey sen sağır mısın?' (...) O an çok utanmıştım. Gizlice yaşlar döküldü gözümden. Utanç gözyaşlarıydı belki de... Herkes bir şeyler karalıyordu, ben ise farklı duygular içerisindeydim."

Connerton yaşamı kavramamızda en önemli kategorinin, neden-sonuç kategorisi değil, anlamlılık olduğuna (Connerton, 1999, s.52) vurgu yapar ve alışkanlık belleğinin işlediği yeri göstermeye çalışır; o yer kural ile uygulama arasında bir boşlukta yer almaktadır. Gündelik hayatın içinde sadece kendimize aitmiş gibi düşündüğümüz davranış setlerinden pek çoğunun aslında genel hikâyenin bir parçası olduğunu, pek çoğunun da nereden ve nasıl kendi hikâyemize katmış olabileceğimiz ise tartışmalıdır. Öte yandan "Toplumsal failler, habitus'un sürekli eğilimleri aracılığıyla mevcut kurumları pratik olarak içselleştirerek etkinleştirirler. Dolayısıyla habitus, belirli türde zeminler ve koşullardaki toplumsal deneyimlerimizin bir sonucu olması yanında, zihnimizde taşıdığımız -sınıf, dil, etnisite, toplumsal cinsiyet gibi- sürekli eğilimler setini anlatır" (akt:Tatıcın, Çeğin: 2014, s.315). Bu nedenle belirli toplumsal ortamlar ve koşullardaki deneyimlerimiz hayatın içindeki tüm etkileşimlerimizi etkilemektedir; yoksullukla ilgili düşünceler -de tıpkı diğer pek çok durumda olduğu gibi- toplumsal olarak yaratılan algılar, kanaatler, ön yargılar içinden bir tanıma kavuşturulmuştur. Burada yer alan örneklerin pek çoğunda, utanma gerekçesinin yoksulluk deneyimiyle ilgili olduğunu görmekteyiz.

SA/K 94 "Gündelik hayat pratiklerimiz bize kimseye boyun eğmemeyi ve çalıp çırpmamayı öğretmişti. Ahlak algımızda namusuyla yaşayan insanlar olmak vardı. Borçlar içinde boğuştuğumuz bir dönemde her cumartesi günü annemle pazara geç saatte gidip insanların para vermeye tenezzül etmediği şeylerin içinden evimizin erzağını toplardık. Bize dayatılan bu hayatı kimse görmez sorgulamaz görmezden gelirdi. Bazı iyi niyetli pazarcılar tezgâhlarında kalan artıkları poşetler verirdi. (...) ancak kimi esnaf ve müşteriler bize sanki kötü insanlarmışız gibi davranırlar kovarlardı. İşte o an çok utanır, ama annemi üzmemek için susardım. (...) O ortamdan uzaklaşmayı, buhar olmayı dilerdim. O dönemler sustum ve başkalarının müsaade ettiği kadar yaşadım. (...)Gündelik yaşam pratiklerimizdeki o küçük cümlelerle, küçük davranışlarla oyunun dışına itildim."

Sartre, utanarak, başkasına yadsınamayan bir mevcudiyet biçimi atfettiğimizi” (akt: Finkielkraut, 1995, s.28) söyler. İnsanın sosyalliğinin altını çizen bir ifade olarak başkası benim özgürlüğümü hem kısıtlayan, hem de sonsuz çeşitlilikte hikâyelerin içinde var olmamı sağlayabilendir. Başkası farklı olandır ama genel olarak ondaki farkı/ farkları görmezden gelir, üzerine düşünmemeyi tercih ederiz. Yoksulluk bu farkların en başında yer alıyor. Yoksulluğun kendi başına bir utanma konusu olduğu gerçeğini bu 
çalışmanın çeşitli örneklerinde tekrarlayan bir biçimde şahit olmaktayız.

Bond, çocukluğun, nedenlerini bilmeden itaat etmeye zorlanılan bir dönem olduğunu vurgulamaktadır (1986, s.16-19) Evlerin düzenlenmesinden, eğitim kurumlarındaki kural ve normlardan, mahalle kültüründe işleyen tüm dinamiklerden amade bir varlık olarak çocukluk dönemi itaatler ve utanmalar alanı olarak iş görmektedir. Bond, tam da bu yüzden toplumun kendi yarattığı şiddet aracılığıyla kendini bir arada tuttuğunu ve bundan en çok zarar görenlerin ise çocuklar olduğunu söylemektedir (1986, s.2223). Ona göre modern dünyanın görkeminin altında bu şiddet var ve ne yazık ki varoluşumuzun ihtiyaç duyduğu estetik, düşünsel gereksinimler temel gereksinimler olmaktan çoktan çıkartılmıştır (1986, s.23-24).

BE/E 95. "ilkokul ikinci sınıfın ikinci döneminde utandığım kadar hayatım boyunca utanmadım. Ben dâhil olayda yer alan herkes çocuktu. (...) ilkokulda ben, İ ve C üç arkadaştık. i Almanya'dan gelmişti. Aynı zamanda da komşuyduk. Birbirimize gider gelir, birbirimizde yemek yer oyun oynardık. Ama sadece bir kapıdan diğerine geçmiyorduk resmen kültürden kültüre ülkeden ülkeye geçiş yapıyorduk. (...) Onlar bizden farklıydı. Onun anne babası sürekli Almanca konuşuyorlardı. Pişen yemekleri yadırgıyordum. (...)Okula gitmediğim bir gün öğretmen herkes bir diğeri hakkında ne düşünüyor onu anlatmasını istemiş. $C$ benim anlattıklarımı biraz da abartarak sınıfta herkesin önünde anlatmış. İ ağlayarak eve gelmiş. (...) Biz üç çocuk kendi halimize bırakılsak o tuhaf gördüğümüz şeylerle birlikte yaşardık ancak annem eve her geldiğimde ne yediğimi neler olduğunu soruyordu. Aslında aileler arasındaki farkı bu sorularla anladık diyebilirim. İşin içine aileler karışınca farklılıkları görmeye başladık."

John Stuart Mill'e göre, uygarlığın ilk dersi, itaat dersidir (akt Arendt, 1997, s.45). Toplum demek, farklı düşünmek, kimi zaman rasyonaliteden kopuş, kimi zaman da marjinal bir alanda yer almak anlamına gelir. Ya da yukarıdaki çoğu örnekte olduğu gibi bir utanmanın kapısını ardına kadar açar. Toplumda yaşamak bizi büyük bir uyumun içine çeker; bu uyum -konformite- neredeyse zorunludur; ancak böylelikle kişiler kendilerini güvende hissedebilirler. Çocukluk, ilk gençlik yılları bu uyum süreciyle geçmektedir. Ancak hayat kimi zaman bu uyumun dışında bir yerlerde konumlanmayı gerekli kılabilir; tıpkı aşağıdaki örnek olayda olduğu gibi. Bazı sosyal vak'alar başa geldiği zaman -boşanma, anne baba ayrılıkları- bunlar yaşamın bir gerçeği olmaktan çok, çoğunlukla utanılacak bir meseleye dönüşebilmektedir. O nedenle de sıra dışı kimi haller/durumlar hayat boyu baş edilemeyen meseleler olarak deneyimlenmektedir.

AK/K 11. "Çocukluğumdan şimdiki yaşıma kadar tabi ki bir sürü unutamadığım anlar oldu. Ama şu anda en net hatırladığım utanma anım, yazarken bile içimi sızlatan bir an. Üniversiteye başladığım yıllarda annemle babam ayrıldılar. Yaklaşık üç sene önce babamın bizden başka bir hayatı, başka bir kadın ve çocuğu olduğunu öğrendim. Bu gerçeği öğrenmeden bir gece önce erkek arkadaşım, erkek arkadaşımın ablası ve ben Çeşme'deydik. Benim gece midem rahatsızlandı erkek arkadaşımdan beni eve bırakmasını rica ettim ve babam beni eve almayıp, İzmir'e annemin evine dönmemi söyledi. (...)Evin kapısından çıkıp, arkadaşımın arabasına giderken hayatımdaki en büyük güven kırıklığını yaşıyordum. Birden sırtım bomboş kalmıştı. Hiçbir şey hissetmiyordum. Arabaya döndüğümde bu durumu son derece garipseyen, anlamlandıramayan iki çift göz benden bir açıklama yapmamı bekliyordu. (...)Baba hasta olan evladını evine almamıştı. 
Hayat, herkesin gördüğü kadarsa eğer, onların gördüğü, bildiği hayat bunu kabul etmeyecekti. (...)Herkesin kendini rahatça ifade edebildiği bir toplumda yaşasaydık, belki ben o gece o kadar utanmazdım."

Bu son cümle, toplum insanane yapar sorusununyanıtı gibi durmakta ve hayatlarımızdaki derin sessizliklerin ideolojilerle akrabalıklarını bir kez daha hatırlatmaktadır. Terry Eagleton İdeoji kitabının başlarında Thom Gunn'un İkinci Dünya Savaşı sırasında Nazilerin elindeki Yahudileri kurtarmaya çalışan Alman askerlerine ithafen yazmış olduğu şiiri örnekler. "Biliyorum, olağan gözleri vardı onun/ Gücünü, hiçbir düzenden almayan gözleri/ Koymazdı gördüğü insanları/ Diğerleri gibi, tanrı ya da böcek katına" Eagleton, insanların birbirlerini zaman zaman tanrı ya da böcek katına koymalarına yol açan şeyin ideoloji olduğunu söyleyecektir. Bu asker yandaşlarının ideolojik koşullandırmalarından kurtuldu ise bunu nasıl başarmıştır? (Eagleton, 1996, s.13-14). Bu soruyla ideolojinin ne olduğuna ilişkin yanıt vermenin zorluğuna işaret eder ama aynı zamanda da ideolojilerden bağımsız insani duyguların harekete geçebildiği bir yerlerin de varlığına işaret etmektedir.

\subsection{Geçmișin Yükü: Bir Hatırlama Alanı Olarak Hatıralar ve İnsan}

Hafıza Bergson'a göre bir çekmecenin muhtelif gözlerine hatıraların yerleştiği deftere geçirilen meleke değildir. Ortada ne defter, ne çekmece ne de meleke vardır. Geçmiş çocukluğumuzdan itibaren bizi yoğurur. Duyup düşündüğümüz deneyimlediğimiz her şey çocukluğumuzdadır (Bergson, 2017, s.78). Bilinçaltındaki bu hazineden bilince çıkanların lüks hatıralar olduğunu söyler. Onları açık olarak seçemesek de geçmişimizin kaybolmadığını duyuran yine bunlardır (2017, s.79). Çalışmaya konu olan tüm anlatılar Bergson'un lüks hatıralar kategorisinde yer almaktadır. Bazı utanç hadiseleri/duyguları bir daha hiç unutulmayacak bir deneyim olarak kalmaktadır. Hayat boyu pek çok zaman diliminde, pek çok utanma hikâyesi yaşanmışsa da, bazıları KH/E 95'de olduğu gibi hem kendisinde, hem diğer yaşayanlarda, hem de yıllar sonra bu deneyimin tanıklığını yapanlarda etki alanı büyük bir duygu yaratmaktadır. Bir köy ortamında salça mevsiminde yaşanan hikâyede kadim zamanlardan kalma bir ahlaki değerlendirmenin izlerini bulmak mümkün. Bu olay sadece bir çocuğun yaramazlığı ve utanç hikâyesi olmaktan çıkmış, köy halkının önemli bir deneyimine dönüşmüştür.

KH/E 95. "Yazın ardından bütün kışı salça kıtlığı ile geçirdik. O dönemlerde salça en pahalı ürünlerden biriydi ve bizim mahalle de ortalama yaşam standartlarının altında insanların yaşadığı bir yerdi. Aradan birkaç ay geçtikten sonra annemin ağlayan yüzü, komşuların sesleri üzerimde giderek ağırlaşmaya başlamıştı. Anneme durumu anlattım. 'komşulara bunu nasıl anlatacağız' dedi. $O$ ana kadar havalar nedeniyle salçaların bozulduğunu sanıyorlardı. Ortaokul birinci sınıftaydım. Annem birkaç gün sonra artık okula devam etmeyeceğimi; evimizden on kilometre uzaklıktaki bir bakliyat dükkânında çırak olarak işe başlayacağımı söyledi. Tam iki yıl boyunca okula gitmedim. Kazandığım parayı ustam babama verirdi. İki yıl sonra annem çalıştı̆̆ım paralarla bütün komşulara salçayı kendisinin yapacağını söyledi. İki yıl gecikmeyle okula başlasam da o mahalleden taşınıncaya kadar o olay her gün birileri tarafından tekrar tekrar hatırlatılı. (...) Hiç kimse o salçalara neden kireç attığımı sormadı. Aileme göre ahlak dışı bir davranışın nedeni yoktur. " 
Leopardi'ye göre "Insan varoluşuna anlamını veren şey, başkalarıyla ilişkimiz ve biriktirdiklerimizdir (Leopardi, 2004, s.20). Hatıralar öğrenci anlatılarında olduğu gibi unutmaya gayret ettiğimiz ama bir gün bir şekilde zihinsel dünyamıza yeniden düşen ya da hayat boyu hiç unutmadığımız türden olabilmektedir. Halbwachs'a göre bir hatıranın kalıcı olması için tek bir olayın varlığı her zaman yeterli değildir; aynı anda bir başka şeyin de olması o anıyı -an'ı- hikâyeler repertuvarının içine yerleşmesini sağlamakta önemli bir unsurdur. (2018, s.73-74). Olan şeyi hatırlatan bir başka şey, deneyimlenen hatırayı kalıcı hale getirmeyi mümkün kılmaktadır. Goffman'ın anlattığı hadiseler de böyle bir durumu ima etmektedir; olan sıradan haller içine bir başka küçük an sıkışır ve yaşanan bu anla birlikte olan sıradan hal yaşanan bir hadisenin bir şekilde parçası haline gelmiştir (2018, s.49-50).

ND/K 64 "Hayatım boyunca hiç unutamadığım ve aşağılandığımı düşündüğüm bir olaydı. Illkokul 3. sınıfta sıff bir matematik işlemini yapamadığım için hocam bana tokat atmıştı. Bu olay benim için hem utandığım hem de küçük düştüğüm bir olaydır. (...) Kendi açımdan bakacak olursam, neyin doğru neyin yanlış olduğunu öğrenmeye çalışırken bir yanlışın tüm doğruları götürdüğü bir sistem içinde kendimi bulmuştum. için sınıfın ortasında yediğim tokat beni utanç verici ve küçük düşürücü bir durumun ortasında bırakmıştı."

Bir matematik işlemini yapamadığı için öğrenci küçük bir uyarı alsaydı büyük bir intimalle unutulan bir gün olacaktı. Hatıranın kalıcı olması öğretmeninden aldığı tepkiyle alakalıdır. ${ }^{2}$ Yusuf Atılgan'ın Aylak Adam romanında başkahramanın eli kitap boyunca anlaşılmaz bir biçimde kulağına gitmektedir. Bu hareketin anlamı, çocukluk döneminde babası tarafından bir utandırılma anına dayanmaktadır (Atılgan, 2014, s.40). İnsan davranışlarının her birini bir anlam haritası içinden okuyabileceğimiz bilgisi böylece sorunlu hale gelmektedir. Maurice Halbwachs "Aslında, erken çocukluk dönemimizi hatırlayamayışımızın sebebi, izlenimlerimizin, biz toplumsal varlığa dönüşmedikçe, hiçbir destek bulamamasıdır" diyor (2018, s.44). Bu desteği, hatırlama işlevini belki de utandırılma duygusu vermektedir. Çocukluk döneminde karşılaşılan ve o ana kadar deneyimlenmemiş utanma halleri bir şekilde zihnin lâbirentlerinde yerini almakta ve hayatın bir yerinde herhangi bir hatırlama vesilesiyle de gün yüzüne çıkmaktadır. Halbwachs bu hatırlamaların bir kısmının da kolektif olduğunu söyleyecektir (2018, s.30-31). Elbette bireysel hatıralar vardır ama hiçbir şey ona göre, güncel toplumsal varlığın eşzamanlı örüntüsünün dışında değildir (2018, s.13). Neredeyse tüm utanma hikâyeleri bu ortak anılar repertuvarından çıkmaktadır.

$\mathrm{CA} / \mathrm{K}$ 20. "ilkokul öğrencisi iken maddi durumumuz çok fazla iyi değildi. Kendime ihtiyacım olan spor ayakkabıyı alamamıştım. Beden eğitimi dersimizin olduğu bir gün spor

2 Kişisel -çocukluk- bir utanma hikâyesi ile bunu şöyle aktarabilirim: ilkokula gidiyordum. Yeni edindiğim arkadaşımla okuldan çıkmış birbirine zıt yönlerdeki evlerimize gitmeden sokakta konuşmaya devam ediyorduk. Önünden geçmekte olduğumuz kaymakamlık lojmanının duvarına sıçrayıp sohbetimize devam ederken bir komşu amca yanımızdan geçti. Ama sadece geçmedi baktı. O bakış ile bizi baş başa bıraktığında kendimizi çok kötü hissettiğimizi ve yavaşça duvardan inerek ayrı yollardan evlerimize gittiğimizi hatırlıyorum. Bu bakış bir tarafıyla çok anladığımız -ayıp, utanç duygusu veren- ama aynı zamanda da hiç tanımlayamadığımız bir bakıştı. Yıllar sonra meslek sahibi olmuş çeşitli deneyimlerden geçmiş insanlar olarak o arkadaşımla aynı kentte yaşamaya ve zaman zaman buluşmaya başlamışık. Bir gün bana, kaymakamlık duvarındaki oturuşumuzdan utanmamızı sağlayan günü ve komşu amcayı hatırlayıp hatırlamadığımı sordu, elbette hatırlıyordum. Her ikimiz da oradaki utanma utandırılma halini yıllarca hiç anlayamamış olmamızı yeniden birer yetişkin olarak konuştuk. Bizler o bakış sonrasında duvarlarda oturmayan çocuklar olmadık ama o kişiyi ve o utandırılma anını da hiç unutmamıştık. Eğer sadece duvarda oturup evlerimize ayrılsaydık belki de o sahneyi bir daha hiç hatırlamayacaktık. Ama o bakış, o beklenmeyen utanma duvarda oturma halimizi hatıraların arasına gizlemişti. 
ayakkabım olmadığı için kıyafetlerimi değiştirdim sadece okul ayakkabımı değiştirmedim. Hepimizi tek sıra halinde dizen hocamız tek tek bize baktı ve sadece ayakkabısı olmayan kişinin ben olduğunu fark etti. Bir sıra öne çıkmamı istedi. Ve bana sorumsuz olduğumu söyleyerek herkesin içinde bağırıp azarladı. Sonrada soyunma odasına gönderip derse almayacağını söyledi. Beni yanına çekip neden ayakkabım olmadığını sorma intiyacı bile duymadı. Ben çok utandım"

Utanma hikâyelerinde olduğu gibi "Günleri değil anları hatırlarız" (Pavese 2005, s.205). Yazılan bütün utanma hikâyeleri bir bakışın, bir kızgınlığın, bir beceriksizlik anının, bir uyumsuzluğun yarattığı duygunun içinden çıkmaktadır. İletişim dediğimiz macera, karar vermelerimizi, hayatı yaşama biçimimizi, kızgınlık ve kırgınlıklarımızın toplandığı, deneyimlendiği yer ise eğer, hemen hepsi bu hatırlamalar ve unutmalar içinde gerçekleşmektedir. Hafıza bizi yanıltır, ama hiç yanılmadan yaşadığımızı sanma hali daha güçlüdür.

GR/K 42. "Küçükken yazları teyzemlerin çeşmedeki yazlığına gider 10- 15 gün orada kalırdım. Teyzemin benden büyük iki tane kız çocuğu var. Bir gün yine teyzemlere yazın kalmaya gitmiştim. Ben daha altı yaşlarındaydım. Akşam yemeğine oturmaya hazırlanıyorduk. Ben teyzemin kızlarının odasına onları yemek çağırmaya gitmeye karar verdim. Tam kapılarını çalacaktım ki R'nın telefonla konuştuğunu duyup geri çekildim. (...) teyzem beni kapının önünde de gördü ve bana kapı dinlemek çok ayıp bir şey özel bir şey konuşuyordur, çabuk yemeğe git dedi. $\mathrm{O}$ an ben hiçbir şey açıklayamadım. Hayatımda aklıma geldikçe hala çok utanırım ve kimseye söyleyememişimdir.

Ancak GR/K 42. metnin sonunda şunları söylemektedir: "Geriye dönüp baktığımda o utandığım an acaba gerçekten kapı dinlemiş miydim diye sorgularım" Connerton, tüm hatırlamaları düşündüğümüzde, onların bize sorulan bir soru ile harekete geçtiğini; bir başkasının zihninin bu hatırlama meselesindeki işlevinin ise kışkırtıcı olduğuna vurgu yapmaktadır. Bir başkasının belleğinin benim belleğime yardıma gelmesi kişiselmiş gibi dursa da başka birçok kimsenin sahip olduğu düşünceler kümesiyle iliş̧i içindedir. Hatırlama bir parçası olduğumuz veya parçası edildiğimiz toplumların maddi ve manevi tüm yaşamlarıyla birlikte gerçekleşir. Bunlar uzak anılarımız olduğu kadar yakın anılarımız için de geçerlidir (Connerton, 1991, s.60). Her hatırlama unutmaları da kapsadığı gibi aynı zamanda da yukarıdaki örnekte olduğu gibi bir itiraf edememe ya da bir tereddüt hâli de içermektedir.

\subsection{Hikâye Anlatmanın Cazibesi}

Mağara duvarlarındaki çizimlerden, sözel dönemin hikâye anlatıcılarına, mektup ve kart postal külliyatından gündelik hayatın içindeki sıradan sohbetlere baktığımızda, insanın nasıl bir hikâye anlatıcısı olduğunu görmekteyiz. "Hatırlanan geçmişleri yaşanmış bu günlere ve beklenen geleceklere bağlamak için intiyaç duyduğumuz dil, kaçınılmaz olarak hikâyenin dilidir" (Randall, 1999, s.101). Kuşkusuz, herkesin bir yaşam macerası ve o macera içinde biriktirdiği kendine özgü hikâyeleri bulunmaktadır. Randall, Bizi Biz Yapan Hikâyeler kitabında doğru soru sorulduğunda, görünürde bellekten çıkmış sayısız anı/hikâye'nin koşa koşa zihne geri döndüğünü söylemektedir (1999: 313). Pessoa ise güncesi diyebileceğimiz Huzursuzluğun Kitabı'nda "Başımıza 
gelmiş olan şeyler, ya herkesi başına gelmiş ya da yalnızca bizim başımıza gelmiştir; ilk durumda bayatlamıştır, ikinci durumda da bizden başkası anlayamaz onları" (Passoa, 2015, s.41) der. Öğrenciler, utanma ile ilgili anlarını aktarırken hikâye dilini tercih ettiklerini görmekteyiz; anlatıya sadece odaklandıkları utanma konusu değil, kendilerini çepeçevre sarmış bulunan duygu, ek bir hatıra, sosyal duruma ilişkin bilgi de taşımaktadır. Anlatılar, yaşanmış olan duygunun gücünü verebilmek için ister istemez bir hikâyeye dönüştürülmektedir. Deneyimlenen şey ne ise, o duyguyu verebilmenin gereği olarak, ortamı hatırlatan her şey, bir şekilde, hikâyenin parçası olmaktadır: Aşağıdaki örnekte görüleceği gibi, tütünden paranın zamanında alınmamış olması, ailenin hayat şartları, anlatının doğal bir parçası haline gelmektedir. Bu durum sözel dönemin masal anlatıcılarını hatırlatmaktadır; bilge anlatıcı hikâyesini kurarken etrafta olup biten şeyleri de masalına eklerdi, uçan bir kuş, yağmurun sesi birden hikâyenin parçası olurdu. Bizler de bir meseleyi anlatırken tıpkı sözel dönemin bilge anlatıcıları gibi çevremizde olup bitenleri de hikâyenin bir parçası yapmaktayız. Anlatmak, hatta bir durumu anlaşıır ve etkili anlatmak bir şekilde hikâyeleştirmeyi gerekli kılmaktadır. Duyguların dışarda kaldığı bir hatıra olamayacağı için, yaşanan şeyler, o günkü duygular eşliğinde bugüne tercüme edilmektedir. Hatıraların aktarılması -sözel ya da yazı fark etmez- geçmişi şimdiye bağlayabilme isteği ve telaşını barındırmaktadır. Deneyimlenen şey her ne ise, gerçekliğine sadık kalınarak, bir fotoğraf çekme şeklinde değil, geçmişin duyguları eşliğinde hatırlanmakta ve anlatılmaktadır. Bir hatıra geçmişi de geçmişe götürebilir; o nedenle anlatı çok katmanlı bir zaman zincirini kapsamaktadır. $\mathrm{Bu}$ anlamda bir sınav ortamında dahi olsa, deneyimlenen an, hatırlama anında bir vak'ya dönüşmekte ve anlatılabilir hale gelebilmesi için bir şekilde hatırlanabildiği duygular eşliğinde hikâyeye dönüştürülmektedir.

IA/E 45. "Ailem çiftçilik yaparak geçimini sağlıyor. Daha doğrusu sağlamaya çalışıyor. Tarlada yetiştirdiği tütünü tüccara satıyor ve beş altı ay sonra parasını anca alıyordu. Ölü fiyatına satılan tütün, geç gelen para ve 6 kardeş... Geçimimizi sağlamakta babam baya zorlanıyordu. Ben o zaman ilkokul 2. Sınıfa gidiyordum. S.S isminde bir sınıf öğretmenimiz vardı. Bir gün bize dergi dağıttı ve bunu aylık olarak vereceğini şu an vermiş olduğunun parasını da yarın için getirmemizi söyledi. Ertesi gün oldu. Ailemin maddi durumu ortadaydı, ben parayı götüremedim. İki gün geçti yine götüremedim. Ama ben her defasında öğretmeni unuttum yalanıyla geçiştirmeye çalışıyordum. Hiç unutmam Cuma sabahı ilk ders, hoca sınıfa girdi. İ parayı getirdin mi? Diye sordu. Ben parayı yine getirmediğim için başımı öne eğdim ses vermedim. Sonra beni masanın yanına çağırdı. Ben gidiyorum ama o an ölmek yerin dibine girmek istiyorum. Şunu da belirtmek istiyorum tüm öğrencilerin önlükleri mavi iken, benimkisi alamadığımız için siyahtı. Yanına gittiğimde masanın üzerinde duran çıtasını aldı ve çıta 3 parçaya ayrııncaya kadar beni dövdü. (...)Ben çocukluğumda böyle bir olay yaşadım ve acısını hala çekiyorum.

Utanmaların demir attıkları yerden fırlamaları, anlatıya dönüşmeleri bir dinleyiciyi de gerekli kılmaktadır. Bu anlatılar, bir sınav ortamında ve bir sorunun hatırlattığı şekliyle gün yüzüne çıkmış, dile getirilmişlerdir. Walter Benjamin Son Bakışta Aşk kitabında, hikâye anlatmanın gündelik hayat içindeki değer yitimine vurgu yapmaktadır. Ona göre artık hiç kimse bir diğerinin hikâyesini merak etmiyor, dolayısıyla da dinlemek istemiyor. Bunun nedenlerini ise apaçık bir şekilde hayat deneyiminin değer kaybetmesine dayandırmaktadır. "Deneyim değer kaybetti, üstelik daha da kaybedeceğe, dipsiz 
bir uçuruma düşeceğe benziyor. Yalnızca dış dünyayı değil, ahlaki dünyayı algılayış biçimimizin de bir gecede, tahayyül edemeyeceğimiz kadar değişmiş olduğunu fark ediyoruz" (Benjamin, 2006, s.77). Hikâyesiz kalmak onları değersiz kılmanın bir sonucu olmuştur. Hikâye anlatıcılığı aslında geçmiş sohbetlerin bir parçasıydı; geldiğimiz hayat şartlarında/ örüntüsünde ise neredeyse sohbet etmenin bir zemini kalmamıştır. İnsanlık uzun zamandan beri sadece küçük enformatif bilgiler içeren konuşmalar içinde beraberliklerini sürdürmektedirler. Sohbetin kalmadığı bir hayatın içinde hikâyelerin de yeri olamayacağı gerçeğiyle yüzleşmek zorunda olan bir insanlıkla karşı karşıyayız.

Benjamin'e göre enformasyon sadece yeni olduğunda bir değer taşır; oysa hikâye enformasyonun yaptığı gibi salt olup biteni aktarmak değildir. Hikâye yaşanılan şeyi anlatıcının hayatının içine gömer, bir gün yeri geldiğinde anlatılacak şey olarak derinliklerden fırlar (2006, s.120-82). Tıpkı öğrencilerin geçmişlerine ait hikâyeleri aktarmalarında olduğu gibi Pandora'nın kutusu açılır ve yıllar sonra gün yüzüne çıkarak, bizleri hayrete düşürecek canlılıkta tekrar hayatın içine katılmış olurlar. "Anılar onlardan bir anlatı oluşturma aşamasından geçirmeksizin gerçekleşmeyeceklerdir" (Augê, 1999, s. 62-63). Her bir hatırlama yeniden bir hikâye kurmaktır.

J.J. Rousseau'nun İtiraflar'ı hayat boyu utandığı, utandırıldığı deneyimlerinin hikâyesidir. Misafir olarak kaldığı evde bir tarağın dişlerini kırdığın şüphesiyle suçladıktan yıllar sonra konuya ilişkin şunları söyleyecektir: "Bu olay üzerinden yaklaşık elli yıl geçti. Fakat Tanrıya yemin ederim ki ben suçsuzum. Ne tarağa dokunmuş, ne de tarağın dişlerini ben kırmıştım" (Rousseau, 2008, s.22-23). Rousseau'nun utancı ile araştırmaya konu olan öğrencilerin utanmaları arasında bir farkın olmadığını görmekteyiz. Küçük gündelik şeyler aslında hayatımızın önemli hikâyeleri arasında yerini almaktadır. Utanma bir yanıyla gündelik ilişkileri belirlerken, aynı zamanda da etik alanın inşasında önemli bir işleve sahip olmaktadır. Çok şükür, iyi ki hâlâ bir utanç duygumuz bulunmak ne kadar doğru bir cümleyse, ne yazık ki hâlâ pek çok şeyden utanmak zorunda bırakılıyoruz da aynı şekilde doğru olarak kabul edilmelidir. Utanma/ utanç duygusu birbirimizle kurduğumuz ilişkiyi nezaketli bir alanına çekme gücüne sahip bulunmaktadır; ama aynı zamanda, yukarıdaki örneklerde oluğu gibi ruhumuzun eksilen parçalarında hem bizi hem hayatı sersemletmeye de devam etmektedir.

\section{Sonuç}

Utanç duygusuyla ilgili deneyimler bize üç temel tema sunmuştur. Bunlardan ilki edindiğimiz değerler haritasının toplumsal kodlarla yakından ilişkili olduğudur. Utanırız, çünkü toplumsal olarak kabul ettiğimiz değerler bu duygu için yeterli zemini hazırlamaktadır. Utanç kişisel olduğu kadar toplumsal olarak kabul ettiğimiz değerler içinde kendisini var etmektedir. Anlatılan utanma anılarının bu kültürel kodlarla ilişsisi önemli bir tema olarak çıkmıştır. İkinci olarak, utanma ile geçmişi hatırlama arasında doğrudan bir iliş̧i saptanmıştır. Hatıralar pek çok duyguyu taşıyabilir ama utanç duygusu bunlar içinde önemli bir yere sahiptir. Utanç bir meseleyi hatırlama konusunda güçlü bir neden oluşturmaktadır. Bir diğer çıktı ise utanç ve hikaye anlatma arasındaki 
ilişkidir; bu ilişki utancın trajik yönleri ile alakalıdır ve insanlar için unutulmazlıklar arasında yer alarak hikayeye dönüşmektedir.

Gündelik hayat geçip gider, çocukluk geçip gider, ancak kimileri için sıradanmış gibi duran bazı haller başkaları için hiç de sıradan değildir; utanç duygusu böylesi farklı etkiler yaratan, insan ve insan arasında etik bir alan açan önemli bir duygu olarak karşımıza çıkmaktadır. Toplum bir utanma ve utandırmalar alanı olarak işlemektedir. Çalışmada dikkat çeken en önemli hususlardan birisi utanma ile çocukluk arasındaki ilişkinin derinliği olmuştur. Anlatılan utanma anlarından pek çoğu, öğretmen öğrencianne baba ve çocuklar arasında geçmekte ve hatırlanan deneyimlerin içerikleri de çocukluğun her çocuk için bir cennet ve masumiyet zamanları olmadığını göstermektedir. Bu nedenle çocukluk inmal edilmiş bir evre olarak karşımıza çıkmaktadır. Utanma, utandırıma çocuklar için bir öğrenme alanı olmaktan çok, anlamlandıramadıkları bir duygu olmaktadır. Böylece gündelik hayatın sıradan gündelik halleri -çalışmanın gösterdiği gibi- kişisel gelişimlerinin zorlu hikâyelerine dönüşmektedir.

Öte yandan utançla ilgili anlatılar aynı zamanda insanın hatırlama deneyimi üzerine de düşünmemizi sağlamıştır. Utanç duygusu ile geçmişi hatırlama arasında güçlü bir bağ olduğu anlaşıımaktadır. Hatırlanan deneyimler, geçmişin izini taşımakta, ama aynı zamanda da bugünün duygusuyla geçmişin duygusunun karıştığı bir zaman dilimi yaratmaktadır. Bu anlatılar insan, hafıza ve hatırlama üzerine yeniden düşünmemizi sağlamıştır. Utanma duygusu başlı başına bir hatırlama konusu olarak karşımıza çıkmaktadır; deneyimleyen üzerinde derin izler bırakma gücüne sahip bir duygu olarak da hatıralara güçlü bir şekilde eklemlenmektedir. İnsan ile insan arasındaki iletişimde geçmişin izi ve hatıraların gücünü göstermesi bakımından utanç duygusu önemli bir yerde durmaktadır

Utanç, güçlü bir duygu olması hasebiyle, anlatıya dönüştüğünde, hikâyeleştirme sürecine tabi kılınmaktadır. Utanma ile ilgili bir an anlatılırken aslında içinde bulunulan ekonomik durum, babanın terk etmiş̧iği, o günlerde ne hissettikleri de hikâyenin bir parçası olmaktadır. Hatırlama bir an meselesi gibi dursa da, yaşam evreninin içinde diğer olup bitenlerle de çok alakalı olduğu anlaşılmaktadır. Bu anlamda, tüm yaşam aslında, küçük hikâyelerin bir bileşkesi olarak çıkıyor karşımıza; utanç çok küçük bir anda olup bitmiş olsa dahi, o an büyük bir vak'a olarak hatırlanmakta ve bütünlüklü bir hikâyeye dönüştürülmektedir.

Agamben "Modern insan akşam evine -eğlenceli ya da sıkıcı, sıra dışı ya da sıradan, korkunç ya da keyifli- bir sürü olay yaşamış ve tükenmiş olarak döner ama bu olayların hiçbiri deneyime dönüşmemiştir. Bugün gündelik yaşamı -geçmişte hiç olmadığı kadar- dayanılmaz kılan şey onun deneyime çevrilemezliğidir” demektedir (2010, s.16). Ona göre artık hiç kimsenin bir deneyimin hakikatini garantilemeye yetecek otoritesi bulunmamaktadır. Bugün deneyimin sonlanmadığını ama yer değiştirdiğini belirtmektedir. Deneyim artık seyredilen, biriktirilen, takip edilen hikâyelerin içinden çıkmıyor, günümüz insanı daha çok deneyim alanlarının resimlerini çekerek bir başka pozisyon almış durumdadır (2010, s.17). Hiç kimsenin bir diğerinin hüznünü, 
deneyimlediği bir hikâyeyi dinlemeye aday olmadığı bir yaşamın içinde bulunmaktayız. O yüzden, bireyselleşmiş toplumun üyeleri olarak bir diğerinin hikâyesini merak etmedikçe, insan ile insan arasındaki ilişkide ahlaki sorumlulukların giderek daha da sorunlu hale geleceğini görebiliriz.

\section{Kaynakça}

Agamben, G. (2010). Çocukluk ve Tarih- Deneyimin yıkımı üzerine bir deneme, (Çev., Betül Parlak), İstanbul: Kanat.

Arendt, H. (1994). İnsanlık Durumu, (Çev., Bahadır Sina Şener), İstanbul: İletişim.

Arendt, H. (1997). Şiddet Üzerine, (Çev., Bülent Peker), İstanbul: İletişim.

Atılgan,Y. (2014). Aylak Adam, İstanbul: YKY.

Augê, M. (1999). Unutma Biçimleri, (Çev., Mehmet Sert), İstanbul: Om.

Bauman, Z. (2005). Bireyselleşmiş Toplum, (Çev., Yavuz Alagon), İstanbul: Ayrıntı.

Benjamin, W. (2006). Son Bakışta Aşk, (Çev., Nurdan Gürbilek), İstanbul: Metis.

Bergson, H. (1947). Yaratıcı Tekâmül, (Çev., Mustafa Şekip Tunç), Ankara: Milli Eğitim Basımevi.

Bergson, H. (2017). Yaratıcı Tekâmül, (Çev., Mustafa Şekip Tunç), İstanbul: Dergâh.

Bond, E. (1986). "Şiddet Üzerine”, Adam Sanat, (Çev., Cevat Çapan), Sayı:6, s:16-26

Boudelaire, C. (2007). Paris Kasveti, (Çev., Hasan Anamur, Beki Haleva), İstanbul: Kırmızı.

Bourdieu, P.,Wacquant, L. (2012). Düşünümsel Bir Antropoloji Için Cevaplar, (Çev., Nazlı Ökten), İstanbul: Illetişim.

Calhoun, C. (2014). "Bourdieu Sosyolojisinin Ana Hatları" Ocak ve Zanaat, Pierre Bourdieu Derlemesi, (Der.) Güney Çeğin, Çeğin Güney, Göker Emrah, Arlı Alim, Tatılıan Ümit İstanbul: İletişim. 77-127

Connerton, P. (1999). Toplumlar Nasıl Anımsar, (Çev., Alâaddin Şenel), İstanbul: Ayrıntı

Duerr, H., P. (1999). Çıplaklık ve Utanç Uygarlaşma Sürecinin Miti, (Çev., Tarhan Onur, Ankara: Dost.

Eagleton, T (1996). İdeoloji , (Çev., Muttalip Özcan), İstanbul: Ayrıntı.

Finkielkraut, A. (1995). Sevginin Bilgeliği, (Çev., Ayşen Ekmekçi), İstanbul: Ayrıntı.

Freud, S. (1975). Kitle Psikolojisi, (Çev., Kâmuran Şipal), İstanbul: Bozak Yayınları.

Goffman, E. (2018). Karşılaşmalar, Etkileşim Sosyolojisinde İki Çalışma, (Çev., Sercan Çalıı), Ankara: Heretik.

Habermas, J. (2001). Iletişimsel Eylem Kuramı, (Çev., Mustafa Tüzel), İstanbul: Kabalcı.

Hall, S. (1992). "Introduction to Media Studies at the Center", Culture, Media, Language, Stuart Hall, Dorothy Hobson, Andrew Lowe and Paul Willis (ed.), Routledge, London. 117-12.

Halbwachs, M. (1992). On Collective Memory, Edited, Translated, and with an Introduction by: Lewis A. Coser, The University of Chicago Press: Chicago and London.

Halbwachs, M. (2018). Kollektif Bellek, (Çev., Zuhal Karagöz), İstanbul: Pinhan.

Hatchkiss, S. (2014). Narsistik Bir Dünyada Hayatta Kalma Rehberi, (Çev., Ahmet B. Pekiner), İstanbul: Kuraldışı. 
Heller, A. (2006). Bir Ahlak Kuramı, (Çev., Abdullah Yılmaz, Koray Tütüncü, Ertürk Demirel), İstanbul: Ayrıntı.

Herzog, C., Hande, C., Hitters, E. Analyzing Talk and Text II: Thematic Analysis https:www.researchgate.net/publication/321197933 Analyzing_Talk_Analysis_and_Text_II_ Thematic (erişim tarihi: 09. 02. 2019)

Huizinga, J. (1995). Homo Ludens, (Çev., Mehmet A. Kılıçbay), İstanbul: Ayrıntı.

Jay, M. (2012). Deneyim Şarkıları, (Çev., Barış Engin Aksoy), İstanbul: Metis.

Koçak, G. (1997). Gözlerindeki şu hüznü gidermek için ne yapmalı?, İstanbul: Oğlak.

Leopardi, G. (2001). Hisseli Kıssalar, (Çev., Kemal Atakay), İstanbul: YKY

McCullers, C. (1991). Küskün Kahvenin Türküsü, (Çev., İpek Babacan), İstanbul: İletişim.

Pavese, C. (2005). Yaşama Uğraşı, (Çev., Cevat Çapan), İstanbul: Can.

Pessoa, F. (2015). Huzursuzluğun Kitabı, (Çev., Saadet Özen), İstanbul: Can.

Randall, W. (1999). Bizi "Biz" Yapan Hikayeler, (Çev., Şen Süer Kaya), İstanbul: Ayrıntı.

Rousseau, J., J. (2008). İtiraflar (1. Cilt), (Çev., Serkan Özburun), İstanbul: Kaknüs.

Sennett, R. (2002). Karakter Aşınması, (Çev., Barış Yıldırım, İstanbul: Ayrıntı.

Sponville, A., C. (2012). Büyük Erdemler Risalesi, (Çev., Işık Ergüden), İstanbul: İletişim.

Taburoğlu, Ö. (2017). Nazar, Başkası Nasıl Görür?, İstanbul: DoğuBatı

Tatııcan, Ü. ve Çeğin, G. (2014). "Bourdieu ve Giddens: Habitus veya Yapının İiliği” Ocak ve Zanaat, Pierre Bourdieu Derlemesi, (der.) Çeğin, G., Göker, E., Arlı, A., Tatlıcan, Ü. içinde. İstanbul: İletişim.303-366.

Tura, S., M. (2015). Madde ve Mana- Rasyonalitenin Kökeni, İstanbul: Metis

Yılmaz, S. (2012). "Her İletişim Bir Mahremiyet İhlalidir ve Her Mahremiyet İhlalinin Bir Haber Değeri Vardır”, Der. Hüseyin Köse, Medya ve Mahrem, İstanbul: Ayrıntı 